\title{
A Paradox: An Empiric Approach to Inflation-Interest Rates Relationship: Evidence from Turkey
}

\author{
Gülgün Çiğdem ${ }^{1, *}$ \\ ${ }^{1}$ Istanbul Gelişim University, Istanbul, Turkey \\ *Corresponding author: Istanbul Gelişim University, Istanbul, Turkey. E-mail: \\ gulguncigdem@gmail.com
}

Received: July 29, 2019 Accepted: August 26, 2019 Published: September 8, 2019

doi: 10.5296/rae.v11i3.15171ＵRL: https://doi.org/10.5296/rae.v11i3.15171

\begin{abstract}
In today's world where the independence of central banks is questioned and the recessionary process is discussed, serious debates are experienced between economists and policy makers regarding the paradoxical relationship between two important macro-economic variables; Is inflation the cause of interest rate or is interest rate the cause of inflation? Determination of the causality and its direction is very crucial for the economies which are trying to extricate themselves from the high inflation - high interest rate spiral. The researchers searching for an answer to these discussions have conducted various analyses to test the validity of the Fisher Effect. In these analyses, inflation rate and nominal interest rate -as per the hypothesis- were considered as the variables. However, economic agents make their decisions depending on real values rather than nominal values. The purpose of this study is to provide a real and up-to-date approach to these debates which actually began in 1700s and have been ongoing in the triangle of financial markets-central banks-policy makers. For this purpose, the monthly averages regarding the 2011:01-2019:06 period of Turkey were calculated based on the Weighted Average Cost of Funding (WACF) daily data of The Central Bank of the Republic of Turkey (CBRT) and subjected to the cointegration analyses with the annual CPI figures. While EngleGranger Test was used to test the long-term relationship, Granger Causality Test was performed to determine the relationship and its direction in the short term through VECM. As a result of the analysis, bilateral causality among variables was determined in the short term. In other words, inflation is a cause of interest rate and interest rate is a cause of inflation. This study makes a contribution to the literature since no study, which detected a bilateral correlation, has been found.
\end{abstract}

Keywords: Inflation, İnterest rates, Cointegration, Monetary policy

JEL: E31, E43, C12, C22 


\section{Introduction}

Inflation refers to a permanent and long-term increase in the price level. Achieving price stability is important, and it constitutes the main objective of central banks today. On the other hand, interest rate is a strong monetary policy instrument used by central banks against inflation; interest rate is the "time risk" of the money. Central banks shape their interest rates, asset prices, expectations and exchange rates by using the policy interest rates. Through policy interest rate decisions, central banks indirectly influence and even shape consumption and investment decisions as well as the price level. As shown in Figure 1, there are actually two types of interest rates used by the Central Bank to influence the interest rates shaping in the market;

i. Policy interest rate is the interest rate applied to the borrowing banks in the weekly repo auctions initiated if it considers necessary to adjust the liquidity in the market.

ii. Borrowing and lending interest rate is the interest rate applied by the central bank to the overnight borrowers and lenders. The difference between these two interest rates is called "corridor" and these two interest rates are called "interest rate corridor." The interest rate, which is calculated by weighting the interest rates applied by the Central Bank to the weekly and overnight borrowings with the lent amounts, is called Weighted Average Cost of Funding (WACF). Therefore, WACF is an accurate indicator that must be used in the evaluation of the interest rate applied by the Central Bank (Eğilmez, 2016).

Both inflation and interest rate are important macro-economic variables revealing the status of economies and are the indicators of underlying problems. In the case of both indicators deteriorating, debates are experienced among policy makers, central banks and economists regarding the existence and direction of the relationship between these two variables. Although it is thought that the discussion started with Irving Fisher's (1930) hypothesis called Fisher Effect, it is seen that this process actually began in 1700s.

As per the macro-economic literature, first of all, real balances are affected as a result of the increase in the price level. The higher price level is another cause for lower real supply of Money. From the Keynesian perspective, the decreased real money supply disrupts all economic balances. In the case of this disequilibrium, bond supply increases, meaning that bond prices decrease and interest rates increase. As a result, there is a positive causality from the inflation rate to the interest rate, which means that an increase to be experienced in inflation will also bring about an increase in interest rates (Asgharpur et al., 2007).

There are different mechanisms regarding the impact of interest rate on inflation as well. The increase in interest rates will also cause an increase in the user cost of capital (Branson, 1979), and this will lead to an increase in the production cost. This cycle will cause an increase in inflation. According to another mechanism, money supply is a function of interest rate; an increase in the interest rate will also increase the money supply, and the increase in the money supply, according to the Quantity Theory, will result in an increase in the inflation in the short and long term (Asgharpur et al., 2007). 


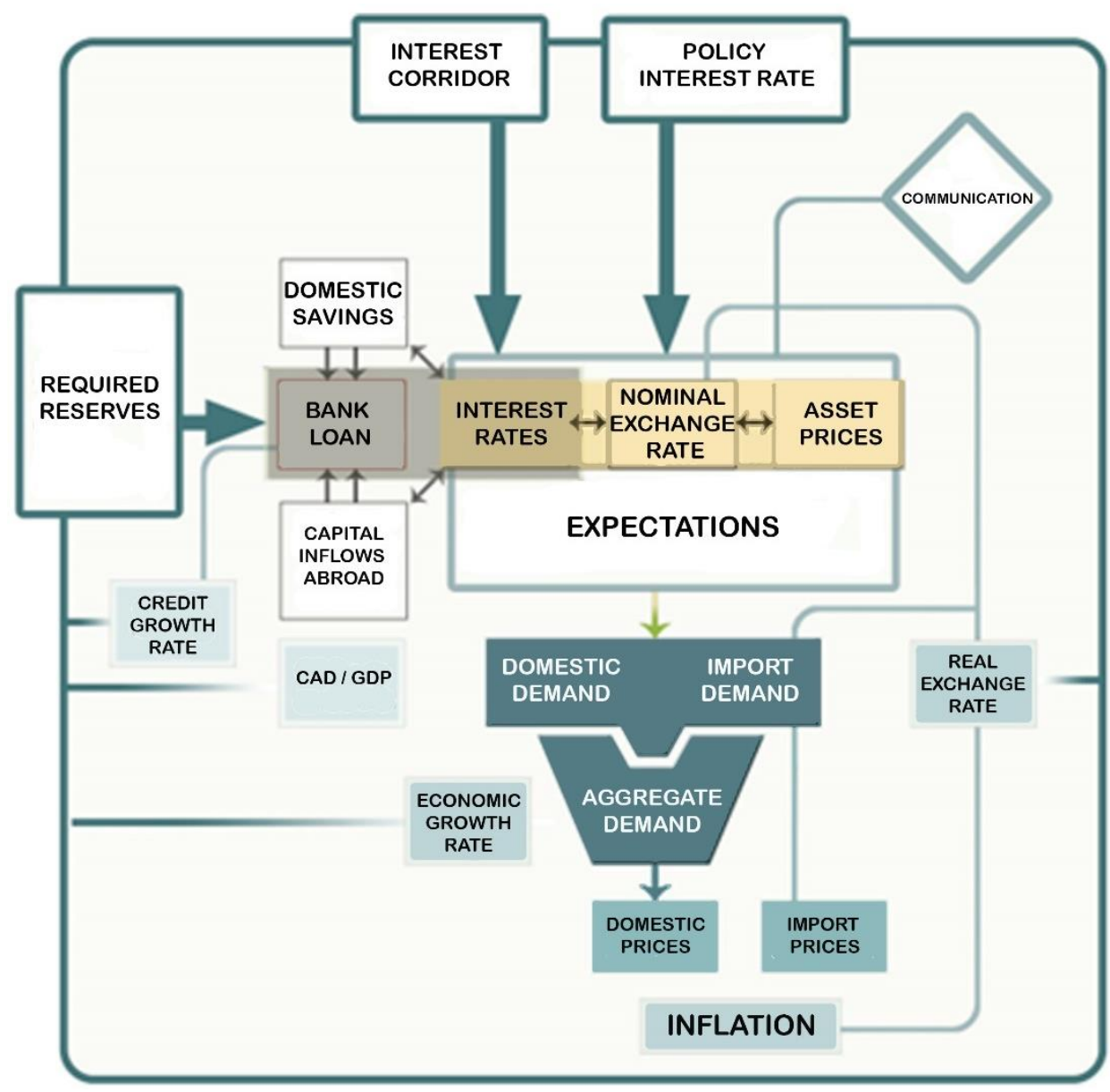

Figure 1. Monetary Transmission Mechanism in Turkey

Source: Central Bank of Turkey.

Since the 1980s, central banks have started to use the "monetary transmission mechanism", which shows to what extent and through which channels the monetary variables affect the total demand, output gap and inflation, in their analyses. The purpose of starting to use this mechanism is to understand through what kind of a process and intensity the monetary policies affect the economy and to share the result with the public. The basic function of the monetary transmission mechanism charted in Figure 1 is to ensure the determination of the inflation rate of the country by directly affecting the production, consumption and employment in the country with the help of monetary policy instruments. The structure and function of the monetary transmission mechanism vary from country to country. Many factors such as the structure and depth of the financial systems, the role and weight of the public sector within the economy and the openness of economies are among the reasons for this difference. The changes occurring in the economic structure at national and global level also give rise to differences in the monetary transmission mechanism. Following the 2008 global financial crisis in Turkey, a new monetary policy component, which aims at decreasing the macro-financial risks resulting from especially external balance and capital flows, was put into effect. In addition to the short- 
term interest rates it uses as policy instruments, the CBRT has started to benefit from various complementary policy instruments such as required reserves, interest rate corridor, liquidity management and reserve option mechanism. The CBRT has also increased the importance attached to the financial stability in addition to the "price stability", which is its main objective. It has been observed that the interest rates, which will provide the price stability and financial stability, may be different from each other, and accordingly, short-term interest rates are not a sufficient policy instrument alone. It has become essential for central banks to use more than one policy instrument. Moreover, in addition to the CBRT's policy interest rate, required reserves and interest rate corridor have started to be used as active monetary policy instruments. The CBRT basically tries to establish the price stability and financial stability by separately affecting loans and exchange rate channels with these new instruments (CBRT, 2013). The emerging positive or negative changes affect spending decisions of consumers and investment decisions of producers. The changes to be made in policy interest rates and interest rate corridor affect exchange rates, interest rates and asset prices. Similarly, interest rates influence national savings and capital inflows. Exchange rates, interest rates and asset prices affect expectations, and expectations affect national demand and import demand and accordingly, aggregated demand. The changes occurring in national and import prices also have an impact on inflation. However, this mechanism causes intensive debates between policy makers and economists.

This study, which approaches these debates that actually started in 1738 with an updated perspective, consists of five sections; following the introduction in the first section, empirical studies were examined in the second section. In the third section, the methodology and data set are discussed. The results of the empirical studies examining the existence and direction of the relationship between inflation and interest rate are provided in the fourth section. In the conclusion, which is the fifth and final section, the study was completed with interpretations with reference to the findings.

\section{Literature Review}

"Irving Fisher, now generally regarded as the father of real/nominal interest rate analysis, originated none of the concepts now bearing his name. Neither the so-called Fisher relationship (according to which the nominal rate equals the real rate plus expected inflation), nor the Fisher effect (according to which the nominal rate fully adjusts for inflation leaving the real rate intact), nor the Fisher neutrality proposition (according to which equilibrium nominal rate adjustments entail no real effects) originated with him. Rather they long predate him, having been enunciated by earlier generations of writers" (Diamond \& Betancourt, 2012).

These causality relationship debates, which are intensively experienced today, actually date back to William Douglas (1738) in the 1700s. Douglas was presumably the first to discriminate between real interest rate from nominal interest rate. Following Douglas, Henry Thornton (1802) used this idea to explain nominal and real interest rate relationship. Thornton (1802) made the first rigorous and systematic explanation of a mechanism by which inflation premium was included in interest rates. Researchers [John Stuart Mill (1865), Alfred Marshall (1890), Jacob de Haas (1889), John Bates Clark (1895) and Fisher (1896)] discussed this causality 
relationship. However, these authors did not refer to Thornton's contribution because they did not know his contribution. Marshall (1890) was the first person to use real and nominal interest rate words. He was also the first to calculate the real value of inflation. In addition, Alfred Marshall (1890) described the relationship between nominal interest rate and inflation as follows (Equation 1) (Humprey, 1983);

$$
r=n-p-n p
$$

In this equation, $r, n$ and $p$ stand for real interest rates while $n p$ shows the cross effect of the nominal interest rate and inflation rate. Therefore, -according to Marshal's view- there is a positive relationship between nominal interest rate and inflation.

John Bates Clark (1895) uses the fixed real interest rate as base. According to Clark, nominal interest rate should be changed proportionally with inflation rate (Equation 2) (Humprey, 1983);

$$
r=n-p
$$

wherewith $r, n$ and $p$ are real interest rate, nominal interest rate and expected inflation rate, respectively.

"In Appreciation and Interest (1896), Fisher drew attention to statements by William Douglass, John Stuart Mill, Alfred Marshall, Jacob De Haas, and John Bates Clark of how expected inflation or deflation affects nominal interest, and he made no claim to originally on the point". "Fisher was the first to write down the relation as an equation, but not the first to articulate the relation" (Dimand, 1999). Fisher (1896), referring to the works of his predecessors, drived the following formulas (Equation 3 - 4);

$$
\begin{aligned}
& r=n-p-n p \\
& n=r+p+r p
\end{aligned}
$$

wherewith $r, n$ and $p$ indicates real interest rate, nominal interest rate and the rate of price inflation, in order of. The relationship between inflation and interest rate was also confirmed by Mundel (1963), Tobin (1965), Darby (1975), Nelson\&Schewert (1977), Mishkin (1981, 1988), Gibson (1972), Booth and Ciner (2001) (except one case), Brazoza and Brzezine (2001), Fave and Auray (2002). However, in their studies, Huizinga \& Mishkin (1984), Barsky (1987), Mishkin (1992) and Ghazali (2003) concluded that there was not a strong relationship between these variables.

Fisher (1930) brought the Fisher Effect in the literature by formulating the relationship between these two important variables. According to the Fisher Effect, nominal interest rates are in a positive interaction with inflation in the long term. This trend has been proven with many studies conducted and using especially a wide data range. In the short term, the Fisher Effect was not supported due to the disequilibrium of the variables. As shown in Table 1, the studies were mostly conducted to test the validity of the Fisher Effect. 


\section{Ml Macrothink}

Research in Applied Economics

ISSN 1948-5433

2019, Vol. 11, No. 3

Table 1. Literature

\begin{tabular}{|c|c|c|c|}
\hline \multicolumn{4}{|c|}{ Studies Supporting Fisher Effects } \\
\hline Researcher & Period/Country & Method & Result \\
\hline Kesriyeli (1994) & $\begin{array}{l}\text { 1980:Q1-1993:Q4 } \\
\text { Turkey }\end{array}$ & Johansen Cointegration & $\begin{array}{l}\text { Long period of time relation between } \\
\text { nominal interest rate and inflation rate. }\end{array}$ \\
\hline Pelaez (1995) & $1959-1993$ & Cointegration tests & Cointegration between variables \\
\hline Berument et al (1999) & $\begin{array}{l}\text { 1958:4-1994:4 } \\
\text { UK }\end{array}$ & $\begin{array}{l}\text { Autoregressive Conditional } \\
\text { Heteroscedastic models }\end{array}$ & $\begin{array}{l}\text { "increased inflation uncertainty results } \\
\text { in raising the nominal interest rate." }\end{array}$ \\
\hline Malliaropulos (2000) & 1960-1995, US & $\begin{array}{l}\text { Vector Autoregressive } \\
(\text { VAR) models }\end{array}$ & $\begin{array}{l}\text { Fisher Effect is valid for medium and } \\
\text { long term }\end{array}$ \\
\hline Lanne (2001) & $\begin{array}{l}\text { 1953:01-1990:12, } \\
\text { USA }\end{array}$ & $\begin{array}{l}\text { recently presented method } \\
\text { (Cavanagh, Elliott and Stock } \\
(1995))\end{array}$ & $\begin{array}{l}\text { Fisher Effect is valid for the period of } \\
1953-1979 \text {. }\end{array}$ \\
\hline $\begin{array}{l}\text { Berument and Jelassi } \\
(2002)\end{array}$ & $\begin{array}{l}1966-1998 \\
26 \text { countries }\end{array}$ & ARCH method & $\begin{array}{l}\text { Fisher's hypothesis is not valid in } 9 \text { of } 12 \\
\text { developed countries, not valid in } 7 \text { of } 14 \\
\text { developing countries }\end{array}$ \\
\hline $\begin{array}{l}\text { Atkins and Coe } \\
(2002)\end{array}$ & $\begin{array}{l}\text { 1953:01-2003:12 } \\
\text { Canada and USA }\end{array}$ & ARDL Bounds test & $\begin{array}{l}\text { Fisher Effect is valid for USA and } \\
\text { Canada }\end{array}$ \\
\hline Carneiro et al. (2002) & $\begin{array}{l}\text { 1980:01- 1997:12 } \\
\text { Argentina, Brasil } \\
\text { and Mexico }\end{array}$ & Johansen Cointegration Test & $\begin{array}{l}\text { Fisher Effect is valid for Argentina and } \\
\text { Brasil }\end{array}$ \\
\hline $\begin{array}{l}\text { Lardic and Mignon } \\
(2003)\end{array}$ & G7 Countries & $\begin{array}{l}\text { Engle-Granger } \\
\text { Cointegration }\end{array}$ & $\begin{array}{l}\text { there is a longrun relation between } \\
\text { interest rate and inflation rate. }\end{array}$ \\
\hline Million (2004) & USA & $\begin{array}{l}\text { Threshold Autoregressive } \\
\text { (TAR) test, cointegration } \\
\text { tests }\end{array}$ & Fisher effect is strong for USA \\
\hline Turgutlu (2004) & $\begin{array}{l}\text { 1978:Q1 - 2003:Q4 } \\
\text { Turkey }\end{array}$ & $\begin{array}{l}\text { Engle-Granger cointegration, } \\
\text { partial stationary and } \\
\text { fragmented cointegration } \\
\text { tests }\end{array}$ & $\begin{array}{l}\text { According to Engle-Granger Test Fisher } \\
\text { Hypothesis is not valid }\end{array}$ \\
\hline $\begin{array}{l}\text { Granville and Mallick } \\
\text { (2004) }\end{array}$ & $\begin{array}{l}1900-2000 \\
\text { England }\end{array}$ & Johansen cointegration test & $\begin{array}{l}\text { There is a longrun association between } \\
\text { inflation and nominal interest rate. } \\
\text { Fisher's hypothesis is valid. }\end{array}$ \\
\hline $\begin{array}{l}\text { Bajo-Rubio et al. } \\
(2005)\end{array}$ & $\begin{array}{l}\text { 1963:Q1 - 2002:Q4 } \\
\text { Spain }\end{array}$ & cointegration & $\begin{array}{l}\text { There is a nonlinear cointegration } \\
\text { connection between inflation and } \\
\text { nominal interest rate. Fisher effect is } \\
\text { valid. }\end{array}$ \\
\hline $\begin{array}{l}\text { Şimşek and Kadilar } \\
\text { (2006) }\end{array}$ & $\begin{array}{l}\text { 1987:Q1 - 2004:Q4 } \\
\text { Turkey }\end{array}$ & ARDL test & $\begin{array}{l}\text { there is a association between interest } \\
\text { rate and inflation in the long period of } \\
\text { time }\end{array}$ \\
\hline Westerlund (2006) & $\begin{array}{l}\text { 1980:01-1999:12 } \\
14 \text { OECD countries }\end{array}$ & panel cointegration analyse & Fisher's hypothesis is valid. \\
\hline $\begin{array}{l}\text { Gül and Açıkalın } \\
(2008)\end{array}$ & $\begin{array}{l}\text { 1990:01-2003:12 } \\
\text { Turkey }\end{array}$ & Johansen Cointegration Test & Fisher's hypothesis is valid vigorously \\
\hline Westerlund (2008) & $1980-2004$ & two new panel cointegration & Fisher's hypothesis is valid. \\
\hline
\end{tabular}




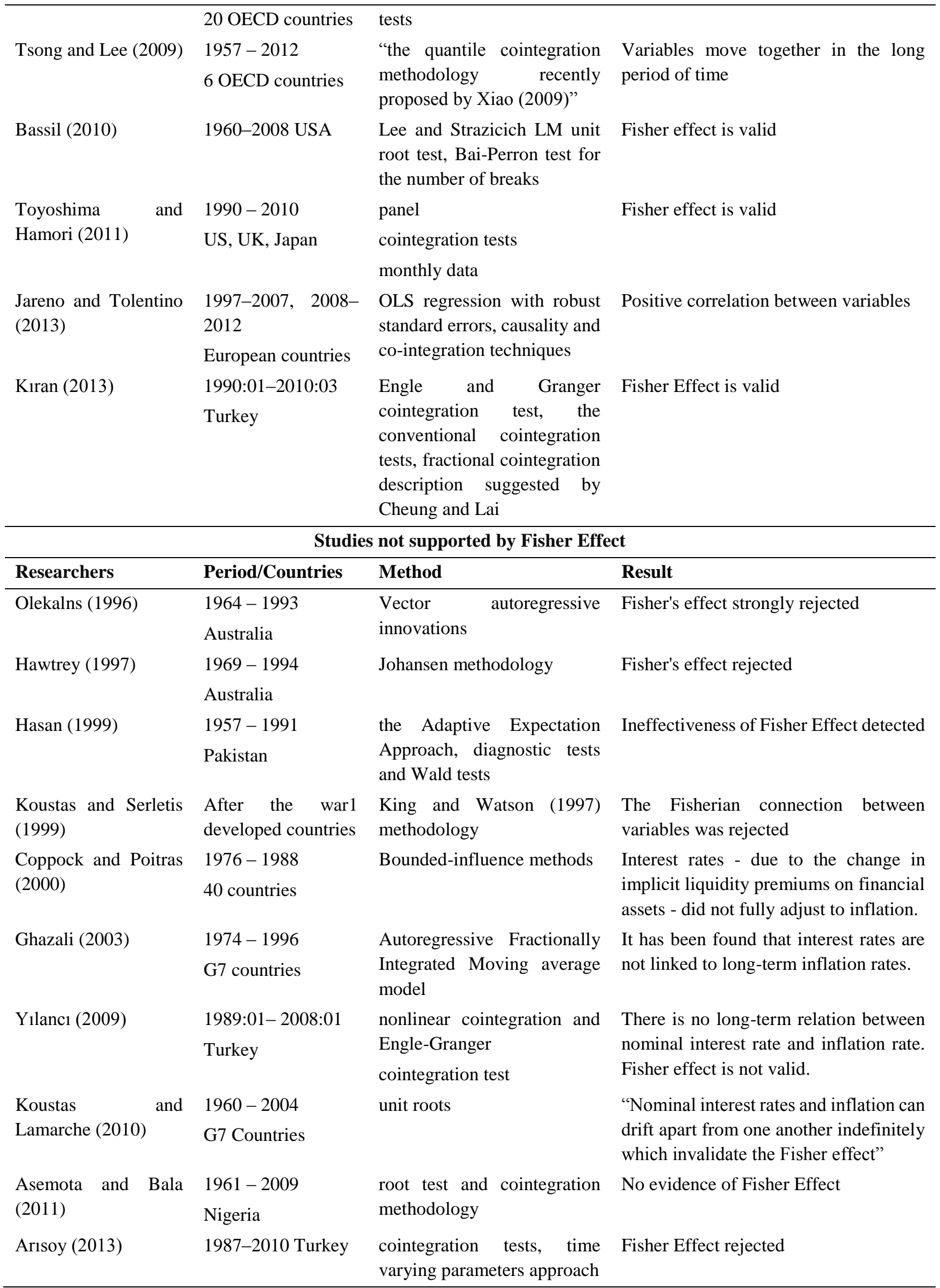




\section{Al Macrothink}

Research in Applied Economics

ISSN 1948-5433

2019, Vol. 11, No. 3

Table 2 shows the empirical studies conducted regarding the direction of the causality between inflation and interest rate and the direction of the causality detected in the analysis results. Oneway causality relationship from inflation to interest rate or from interest rate to inflation was determined in these studies.

Table 2. Literature

\begin{tabular}{|c|c|c|}
\hline \multicolumn{3}{|c|}{ INFLATION $\rightarrow$ RATE } \\
\hline Researchers & Period/Country & Method \\
\hline Barthold and Dougan (1986) & $1902-1983$, USA & Time Series Analysis \\
\hline Hutchison and Keeley (1989) & 1953 - 1986, USA & Time Series Analysis \\
\hline McDonald and Murphy (1989) & 1955 - 1986, developed 4 countries & Vector Error Correction Model \\
\hline Gupta (1991) & 1968:Q4-1985:Q4, USA & Time Series Analysis \\
\hline Woodward (1992) & 1982:04-1990:08, England & Time Series Analysis \\
\hline \multirow[t]{2}{*}{ Phylaktis and Blake (1993) } & 1971:Q1-1991:Q3 & Vector Error Correction Model \\
\hline & Argentina, Brasil, Mexico & \\
\hline \multirow[t]{2}{*}{ Peng (1995) } & 1957:Q1- 1994:Q2 & Time Series Analysis \\
\hline & 5 Industrialized Countries & \\
\hline Pelaez (1995) & 1959:Q1-1993:Q4, USA & Johansen Cointegration Test \\
\hline Daniels et al. (1996) & 1957:Q1 - 1992:Q4, USA & Causality Test, Johansen Cointegration Test \\
\hline Olekalns (1996) & 1965 - 1990, Australia & Time Series Analysis \\
\hline Engsted (1996) & 1948 - 1989, Denmark & VAR Analyse \\
\hline Doğan, Eroğlu and Değer (2016) & 2003:01 - 2015:02 & Granger Causality Test \\
\hline \multirow[t]{2}{*}{ İşcan and Kaygısız (2019) } & 2009:01-2017:12 & Granger Causality Test, VAR \\
\hline & Turkey & Autoregressive Model) model \\
\hline \multicolumn{3}{|c|}{ RATE $\rightarrow$ INFLATION } \\
\hline Researchers & Period/Country & Method \\
\hline \multirow[t]{2}{*}{ Asgharpur et al. (2007) } & $2002-2005$ & panel data methodology, Wald Test \\
\hline & 40 selected Islamic Countries & \\
\hline Yamak and Tanrıöver (2007) & 1990 - 2006, Turkey & Granger Causality Test \\
\hline Akınc1 and Y1lmaz (2016) & $1980-2012$, Turkey & $\begin{array}{l}\text { Dynamic Ordinary Least Squares (DOLS) } \\
\text { analysis, Johansen-Juselius cointegration, } \\
\text { Granger Causality Test }\end{array}$ \\
\hline
\end{tabular}

Following the literature review, the analysis phase was initiated with an aim to reveal the existence of the relationship between inflation and interest rate and the direction of causality.

\section{Methodology and Data Set}

For testing the existence and direction of the relationship between inflation and interest rate in Turkey, 102 observations were created on a monthly basis by obtaining the inflation data of 2011:01 - 2019:06 period (annually, \%) from the Central Bank of the Republic of Turkey (CBRT) and CBRT Weighted Average Cost of Funding (WACF) data (daily, \%). As seen in 


\section{I Macrothink}

Research in Applied Economics

ISSN 1948-5433 2019, Vol. 11, No. 3

Figure 1 created with reference to the data, inflation and CBRT WACF show parallelism in Turkey. In the period of 2011:01-2019:06, CBRT WACF experienced maximum levels in April 2019 with $24.438 \%$ and minimum levels in September 2011 with 5.75\%. Inflation experienced maximum levels in September 2018 with 24.52\% and minimum levels in March 2011 with $3.99 \%$.

Engle - Granger Cointegration analysis was performed to test whether the series cointegrated in the long term. Following the cointegration detection, Granger Causality Analysis was performed through VECM (Vector Error Correction Model). E-views 8.0 software was used in the analyses. The variables examined are shown in Table 3. Since the series used had different characteristics (annually and monthly), they were converted to logarithmic form and coded with linf and lrate symbols, respectively.

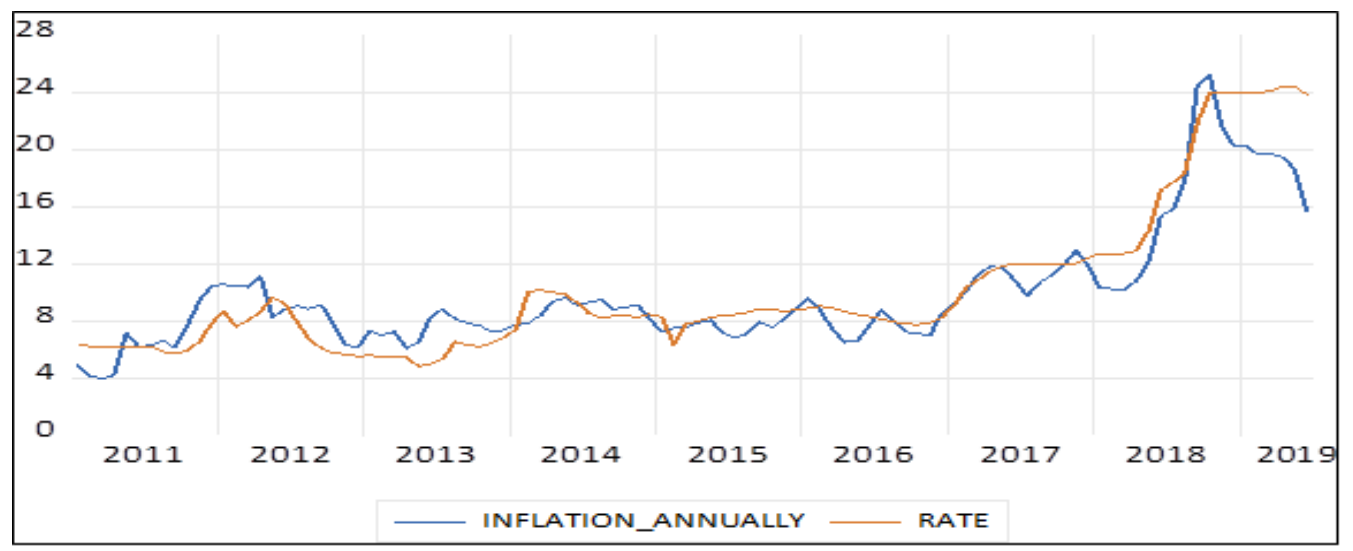

Figure 2. Inflation and WAFC in Turkey, 2011:01-2019:06

Source: Created by the Author.

Table 3. Variables

\begin{tabular}{lllcl}
\hline Variables & Obtaining & Abbreviation & Unit & Type of Use \\
\hline Inflation rate & Consumer price index & INF & $\%$ & Logarithmic \\
Interest rate & CBRT WAFC & RT & $\%$ & Logarithmic \\
\hline
\end{tabular}

Source: CBRT EDDS.

It is possible to formulate interest rate as a function of inflation as follows (Equation 5):

$$
\mathrm{RT}=f(\mathbf{I N F})
$$

$R T:$ Interest rate

INF : Inflation 
When the literature is examined, it is seen that there are studies justifying that interest rates are a function of inflation (Equation 5); Barthold and Dougan (1986), Hutchison and Keeley (1989), McDonald and Murphy (1989), Gupta (1991), Woodward (1992), Phylaktis and Blake (1993), Kesriyeli (1994), Pelaez (1995), Peng (1995), Daniels et al. (1996), Olekalns (1996), Engsted (1996), Berument et al. (1999), Malliaropulos (2000), Lanne (2001), Berument and Jelassi (2002), Atkins and Coe (2002), Carneiro et al. (2002), Lardic and Mignon (2003), Million (2004), Turgutlu (2004), Granville and Mallick (2004), Bajo-Rubio et al. (2005), Şimşek and Kadılar (2006), Westerlund (2006), Gül and Açıkalın (2008), Westerlund (2008), Tsong and Lee (2009), Bassil (2010), Toyoshima and Hamori (2011), Jareno and Tolentino (2013), Kiran (2013), Doğan, Eroğlu and Değer (2016), İşcan and Kaygısız (2019) detected the existence of a causality relationship from INF to RT in their empirical studies.

Before starting the analyses, as also stated by Granger and Newbold (1974), unit root analyses were performed on the variables with an aim to eliminate the problem of spurious regression expressed as the existence of unsubstantial relationships. In order to determine whether the variables are stationary and to what extent they are stationary if they are stationary, unit root analyses of PP (Phillips - Perron) developed by Phillips and Perron (1988) and ADF (Augmented Dickey - Fuller) developed by Dickey and Fuller $(1979,1981)$ were used. Equation 6 and equation 7 functionally represent the PP unit root analysis of the fixed ADF test, respectively;

$$
\begin{gathered}
\Delta y_{t}=\beta+\delta y_{t}+\sum_{i=1} \emptyset i \Delta y_{t-1}+\varepsilon_{t} \\
y_{t}=\beta_{0}+\delta_{1} y_{t-1}+\varepsilon_{t}
\end{gathered}
$$

In these equations, the observation number was formulated with $\mathrm{T}$, the distribution of the error terms with $\varepsilon_{t}$, the series where the test is applied with $y_{t}$ and the trend variable with $\alpha, \beta$ and t. Hypothesis is as

$H_{0}$ : Series is not stationary (there is a unit root in the series)

$H_{1}$ : Series is stationary (there is no unit root in the series)

If the hypothesis $H_{0}$ is rejected, i.e. if Test Statistics <Critical Values, the variable $y$ is stationary. In the contrary case, it is not stationary, and it is unit-rooted (Yamak and Küçükkale, 1997). In this case, it is necessary to calculate the difference of the series.

As a result of the unit root analysis, after it was detected that the variables were stationary at the same level $\left(I_{1}\right)$, cointegration step was followed and Engel - Granger (1987) Test was applied to the series to test the existence of the long-term relationship between the variables. In order to test the cointegration between the series, each variable needs to be integrated at least at first-degree and the cointegration degrees of the variables also need to be equal (Enders, 1995). In the first phase of the Engle - Granger method, the prediction of the error term is performed with the Ordinary Least Squares (OLS) method and in the next phase, unit root research is carried out. The following regression is established between the two first-degree stationary variables (Equation 8); 


$$
y_{t}=\propto_{0}+\propto_{1} x_{t}+u_{t}
$$

An autoregressive model (Equation 9) is established with the residues obtained from this regression and it is examined whether the residues are stationary or not:

$$
\Delta u_{t}=\rho u_{t-1}+e_{t}
$$

Here, if $\rho=0$, it is possible to state that the residues contain unit root; accordingly, there is no cointegration relationship between the two variables. In the case that the result is stationary, it will be possible to mention the existence of cointegration.

In case of achieving cointegration between the series, the error terms obtained from the cointegration analysis within the scope of the Vector Error Correction Model (VECM) are also added to the causality model. After determining that the series were related in the long term, Granger was applied to the series through VECM (Vector Error Correction Model) with an aim to question the causality relationship and direction of the causality in the long term.

In the time-series econometrics, Wiener (1956) was the first person to mention causality and it began to be widely used with the study of Granger in 1969. It is said that "According to Granger, if the lagged values of $\mathrm{X}$ contribute to the prediction of the values of $\mathrm{Y}$, then $X$ is the Granger cause of $Y^{\prime \prime}$. The standard Granger causality test is based on the prediction of the two-variable VAR model given below in which the lagged values of the variables for the two stationary series on level are included on the right side of the equation (Equation 10-11):

$$
\begin{aligned}
& X_{t}=\sum_{j=1}^{m} a_{j} X_{t-j}+\sum_{j=1}^{m} b_{j} Y_{t-j}+\varepsilon_{t} \\
& Y_{t}=\sum_{j=1}^{m} c_{j} X_{t-j}+\sum_{j=1}^{m} d_{j} Y_{t-j}+\mu_{t}
\end{aligned}
$$

If the relevant F-value calculated here is bigger than the critical value at a certain significance level, " $Y$ is not the Granger cause of $X$ " or the null hypothesis $b_{j}=0$ is rejected and it is said " $Y$ is the Granger cause of $X^{\prime \prime}$.

Engle and Granger (1987) stated that the standard Granger test based on the VAR model would not be acceptable when the series were cointegrated and in this case, the causality relationships between the series needed to be examined with the vector error correction model (VECM). In this case, the VECM is established according to the dependent variables $\mathrm{X}$ and $\mathrm{Y}$ with the purpose of revealing the deviation from the long-term equilibrium, eliminating the disequilibrium in the short and long term and explaining the short and long-term causality relationships. For variables, the following error correction models (ECM) are predicted with the ordinary least squares method (Loizides and Vamvoukas, 2005; Bekhet and Yusop, 2009)(Equation 12-13):

$$
\begin{aligned}
& \Delta X_{t}=\sum_{j=1}^{m} a_{j} \Delta X_{t-j}+\sum_{j=1}^{m} b_{j} \Delta Y_{t-j}+\alpha E C T_{1, t-1}+\varepsilon_{t} \\
& \Delta Y_{t}=\sum_{j=1}^{m} c_{j} \Delta X_{t-j}+\sum_{j=1}^{m} d_{j} \Delta Y_{t-j}+\beta E C T_{2, t-1}+\mu_{t}
\end{aligned}
$$


$E C T_{1, t-1}$ and $E C T_{2, t-1}$ represents the error correction terms while $\alpha$ and $B$ Show the coefficients of error correction terms. $E C T_{1, t-1}\left(X_{t-1}-\alpha_{1} Y_{t-1}\right)$ and $E_{C T} T_{2, t-1}\left(Y_{t-1}-\right.$ $\left.\beta_{1} X_{t-1}\right)$ are respectively the 1-period lagged values of the error term obtained with the prediction of the cointegration equation where $\mathrm{X}$ and $\mathrm{Y}$ are taken as the dependent variables, respectively. $\alpha$ and $\beta$ gives the correction speed of the deviation between the short-term value and long-term value of the dependent variable in one period. For the short and long-term causality relationships, $t$ and $F$ tests are performed. If the coefficient of the error term is significant at a certain significance level (if the calculated t-statistics < critical value, $H_{0}$ is rejected), it means that there is a causality relationship in the long term from the independent variable to the dependent variable or "the independent variable is the Granger cause of the dependent variable in the long term". If the coefficients of the lagged values of the independent variables are significant as a whole, it means that there is a causality relationship in the short term from the independent variable to the dependent variable or "the independent variable is the Granger cause of the dependent variable in the short term".

\section{Empirical Results and Discussion}

In this section, firstly, the unit root analysis results of the variables included in the analysis and then cointegration test results will be discussed. The results of the analysis where the stationariness of the series were tested are given in Table 4. According to the ADF and PP unit root results, variables are stationary at $I_{1}$.

Table 4. Unit Roots Results

\begin{tabular}{|c|c|c|c|c|c|}
\hline & \multirow[b]{2}{*}{ Variable } & \multirow[b]{2}{*}{ Test Statistics } & \multicolumn{3}{|c|}{ Critical Values } \\
\hline & & & $\% 1$ & $\% 5$ & $\% 10$ \\
\hline \multirow[t]{4}{*}{ PP } & linf, level & -2.490338 & -4.051450 & -3.454919 & -3.153171 \\
\hline & linf, level 1 & -8.167787 & -4.052411 & -3.455376 & -3.153438 \\
\hline & lrate, level & -1.772153 & -4.051450 & -3.454919 & -3.153171 \\
\hline & lrate, level 1 & -7.530280 & -4.052411 & -3.455376 & -3.153438 \\
\hline \multirow[t]{4}{*}{ ADF } & linf, level & -3.091264 & -4.052411 & -3.455376 & -3.153438 \\
\hline & linf, level 1 & -8.313992 & -4.052411 & -3.455376 & -3.153438 \\
\hline & lrate, level & -1.981157 & -4.052411 & -3.455376 & -3.153438 \\
\hline & lrate, level 1 & -7.560168 & -4.052411 & -3.455376 & -3.153438 \\
\hline
\end{tabular}

Note. “*** represents a significance level of $1 \%$. The number of delays in the ADF tests is determined according to the Schwarz criteria. The Schwartz criteria is a stronger criterion and gives better results than the others. In the PP tests, the number of delays determined according to Newey-West Bandwith is taken. As a test format, fixed and trend equation options are used for all variables at the level value. The fixed equation option is used to obtain the first difference of the variables. MacKinnon critical values are contemplated." 
Table 5 shows Engle - Granger's first step results.

Table 5. Least Squares Results

\begin{tabular}{lrlrr}
\hline \multicolumn{1}{c}{ Variable } & Coefficient & Std. Error & t-Statistic & \multicolumn{1}{c}{ Prob. } \\
\hline LINFLATION_ANNUALLY & 1.021980 & 0.053923 & 18.95247 & 0.0000 \\
\multicolumn{1}{c}{ C } & -0.045478 & 0.121256 & -0.375057 & 0.7084 \\
R-squared & 0.782228 & Mean dependent var & 2.222845 \\
Adjusted R-squared & 0.780050 & S.D. dependent var & 0.418956 \\
S.E. of regression & 0.196485 & Akaike info criterion & -0.397045 \\
Sum squared resid & 3.860649 & Schwarz criterion & -0.345575 \\
Log likelihood & 22.24928 & Hannan-Quinn criter. & -0.376203 \\
F-statistic & 359.1962 & Durbin-Watson stat & 0.422690 \\
Prob(F-statistic) & 0.000000 & & \\
\hline
\end{tabular}

It was examined whether the regression equation and residues were stationary following the creation of $\varepsilon_{t}$. Engle - Granger Causality Test results are given in Table 6. The statistical value is smaller than the critical values; the inflation and interest rate series are cointegrated in the long term.

Table 6. Engle - Granger Test Results

\begin{tabular}{cccr}
\hline ADF-Statistics & \multicolumn{2}{c}{ Mac Kinnon Critical Values } & Prob. \\
\hline-5.033392 & $1 \%$ & -4.052411 & 0.0004 \\
& $5 \%$ & -3.455376 & \\
& $10 \%$ & -3.153438 & \\
\hline
\end{tabular}

Table 7. Granger Causality Test Results through VECM

\begin{tabular}{lcc}
\hline Hipothesys & Prob & Direction of Causality \\
\hline INF is a Granger cause of RT & $0.0016^{*}$ & INF $\rightarrow$ RT \\
RT is a Granger cause of INF & $0.0026^{*}$ & RT $\rightarrow$ INF \\
\hline
\end{tabular}

*Note: $5 \%$ significance level.

Table 7 shows the Granger Causality Test results through the VECM model and the direction of the relationship determined in the short term; accordingly, there is a bilateral causality between the variables. It means that inflation is a Granger cause of interest rates and interest rates are a Granger cause of inflation. This result differs from the other studies in the literature which determined only unilateral causality.

This result confirms an inference that is logical but different from the results of the studies in 
the literature; an increase experienced in interest rates increases the cost of borrowing, this causes an increase in the cost of production and brings along an increase in the prices of goods and services. Eventually, this will cause inflation. Furthermore, an increase in inflation rates will bring along an increase in interest rates due to the Fisher Effect.

\section{Conclusions}

Discussion of the relationship between inflation and interest rate and its direction in the economies trapped in the high inflation rate - high interest rate spiral and searching for solutions is an important issue that continues to be on the agenda. When this issue is examined, it is seen that it is not a new topic and dates back to the 1700s. These debates among economists and policy makers have brought along various empirical studies. However, as a result of these studies, not only a consensus has not been reached, but also contradictory and different results have been obtained. While some of these studies have confirmed that there is a correlation between these two variables, some have not been able to determine any correlation. Similarly, while some of the studies have found a causality relationship from inflation to interest rates, others have found a causality relationship from interest rates to inflation.

In the study conducted with an aim to contribute to this debate that has been ongoing between economists and central banks whose primary duty is to protect the price stability and where intensive debates are experienced regarding their being independent, the analyses were performed by considering CBRT WACF differently from the previous studies.

The analysis results differed from the literature and a bilateral correlation was found between the variables. From this standpoint, this study contributes to the literature. It will be vital for economies to maintain an interest rate that will not cause inflation and an inflation level that will not increase interest rates. At this point, what should the inflation rate that will not increase interest rate and the interest rate that will not cause inflation be in Turkey? Future studies to be conducted to solve this paradox will be important in terms of central banks and policy makers.

\section{References}

Akıncı, M., \& Yılmaz, Ö. (2016). Enflasyon - Faiz Oranı Takası: Fisher Hipotezi Bağlamında Türkiye Ekonomisi İçin Dinamik En Küçük Kareler Yöntemi. Sosyoekonomi, 24(27), 3355. https://doi.org/10.17233/se.81444

Arısoy, İ. (2013). Testing for the Fisher Hypothesis Under Regime Shifts in Turkey: New Evidence From Time-Varying Parameters. International Journal of Economics and Financial Issues, 3(2), 496-502.

Asgharpur, H., Kohnehshahri, L. A., \& Karami, A. (2007). The Relationships Between Interest Rates and Inflation Changes: An Analysis of Long-Term Interest Rate Dynamics in Developing Countries. Tehran: Iran Economic Research Center. Retrieved from https://www.researchgate.net/publication/267384862_The_relationships_between_interes 
t_rates_and_inflation_changes_An_analysis_of_long-term_interest_rate_dynamics_in_ developing_countries

Asemota, O. M., \& Bala, D. A. (2011). A Kalman Filter Approach to Fisher Effect: Evidence from Nigeria. CBN Journal of Applied Statistics, 2(1), 71-91.

Atkins, F. J., \& Coe, P. J. (2002). An ARDL Bounds Test of The Long-Run Fisher Effect in the United States and Canada. Journal of Macroeconomics, 24(2), 255-266. https://doi.org/10.1016/S0164-0704(02)00019-8

Bajo-Rubio, O., Diaz-Roldan, C., \& Esteve, V. (2005). Is the Fisher Effect Nonlinear? Some Evidence For Spain, 1963-2002. Applied Financial Economics, 15(12), 849-854. https://doi.org/10.1080/09603100500123187

Barthold, T. A., \& Dougan, W. R. (1986). The Fisher Hypothesis Under Different Monetary Regimes. The Review of Economics and Statistics, 68(4), 674-679. https://doi.org/10.2307/1924527

Barsky, R. B. (1987). The Fisher Hypothesis and The Forecast Ability and Persistence of Inflation. Journal of Monetary Economics, 19, 3-24. https://doi.org/10.1016/03043932(87)90026-2

Bassil, C. (2010). An Analysis of The Ex-Post Fisher Hypothesis at Short and Long Term. Economics Bulletin, 30, 2388-2397.

Bekhet, H. A., \& Yusop, N. Y. M. (2009). Assessing the Relationship Between Oil Prices, Energy Consumption and Macroeconomic Performance in Malaysia: Cointegration and VECM Approach. International Business Research, 2(3), 152-175. https://doi.org/10.5539/ibr.v2n3p152

Berument, H. (1999). The Impact of Inflation Uncertainty on Interest Rates in the UK. Scottish Journal of Political Economy, 4(2), 207-218. https://doi.org/10.1111/1467-9485.00129

Berument, H., \& Jelassi, M. M. (2002). The Fisher Hypothesis: A Multi-Country Analysis. Applied Economics, 34, 1645-1655. https://doi.org/10.1080/00036840110115118

Branson, W. H. (1979). Macroeconomic Theory and Policy (2nd ed.). New Jersey: Princeton University.

Brazoza, H., \& Brzezina, M. (2001). The Relationship Between Real Rate Interest Rate and Inflation. Research Department, National Bank of Poland and Chair of Monetary Policy.

Booth, G. G., \& Ciner, C. (2001). The Relationship Between Nominal Interest Rates and Inflation: International Evidence. Journal of Multinational Financial Management, 11, 269-280. https://doi.org/10.1016/S1042-444X(01)00030-5

Carneiro, F. G., Divino, J., \& Rocha, C. H. (2002). Revisiting the Fisher Hypothesis For the Cases of Argentina, Brazil and Mexico. Applied Economics Letters, 9, 95-98. https://doi.org/10.1080/13504850110049405 


\section{Macrothink}

Cavanagh, C. L., Elliot, G., \& Stock, J. H. (1995). Inference in Models with Nearly Integrated Regressors. Econometric Theory, 11, 1131-1147. https://doi.org/10.1017/S0266466600009981

CBTR. (2013). Monetary Transmission Mechanism. https://www.tcmb.gov.tr/wps/wcm/connect/4e99834e-179b-4a08-820c-f2b259032afd/ Parasal Aktarim.pdf?MOD=AJPERES\&CVID=

Clark, J. B. (1895). The Gold Standard of Currency in the Light of Recent Theory. Political Science Quarterly, 10, 389-403. https://doi.org/10.2307/2139952

Coppock, L., \& Poitras, M. (2000). Evaluating the Fisher Effect in Long Term Cross-Country Averages. International Review of Economics and Finance, 9, 181-192. https://doi.org/10.1016/S1059-0560(99)00057-X

Daniels, J. P., Nourzad, F., \& Toutkoushian, R. K. (1996). Testing the Fisher Effect as a Longrun Equilibrium Relation. Applied Financial Economics, 6(2), 115-120. https://doi.org/10.1080/096031096334358

Darby, M. R. (1975). The Financial and Tax Effect of Monetary Policy on Interest Rates. Economic Enquiry, 13, 266-76. https://doi.org/10.1111/j.1465-7295.1975.tb00993.x

De Haas, J. A. (1889). A Third Element in the Rate of Interest. Journal of the Royal Statistical Society, 52, 99-116.

Diamond, R. W., \& Betancourt, R. G. (2012). Retrospectives Irving Fisher's Appreciation and Interest (1896) and the Fisher Relation. Journal of Economic Perspectives, 26(4), 185-196. https://doi.org/10.1257/jep.26.4.185

Dimand, R. W. (1999). Irving Fisher and the Fisher Relation: Setting the Record Straight. The Canadian Journal of Economics / Revue canadienne d'Economique, 32(3), 744-750.

Dickey, D. A., \& Fuller W. A. (1979). Distribution of the Estimators for Eutoregressive Series with a Unit Root. Journal of the American Statistical Association, 74, 427-431. https://doi.org/10.1080/01621459.1979.10482531

Dickey, D., \& Fuller, W. A. (1981). Likelihood Ratio Statistics for Autoregressive Time Series with a Unit Root. Econometrica, 49, 1057-1072. https://doi.org/10.2307/1912517

Doğan, B., Eroğlu, Ö., \& Değer, O. (2016). Enflasyon ve Faiz Oranı Arasındaki Nedensellik İlişkisi: Türkiye Örneği. Çankırı Karatekin Üniversitesi IIIBF Dergisi, 6, 1-21. https://doi.org/10.18074/cnuiibf.258

Douglas, W. (1738). An Essay Concerning Silver and Paper Currency. In A. M. Davis, \& A. M. Kelley (Eds.), Colonial Currency Reprints (pp.1682-1751). Vol. 3. New York 1964.

Eğilmez, M. (2016). Merkez Bankası Faizi Zaten Indiriyor. Retrieved from http://www.mahfiegilmez.com/2016/04/merkez-bankas-faizi-zaten-indiriyor.html

Engle, R. F., \& Granger, C. W. J. (1987). Co-Integration and Error Correction: Representation, 
Estimation, and Testing. Econometrica, 55(2), 251-276. https://doi.org/10.2307/1913236

Enders, W. (1995). Applied Econometric Time Series. New York: Wiley.

Engsted, T. (1996). Non-Stationarity and Tax Effects in the Long-Term Fisher Hypothesis. Applied Economics, 28(7), 883-887. https://doi.org/10.1080/000368496328335

Fave, P., \& Auray, S. (2002). Interest Rate and Inflation in Monetary Models With Ingenious Money Growth Rate. Economic Bulletin, 5(1), 1-10.

Fisher, I. (1896). Appreciation and Interest. New York.

Fisher, I. (1930). The Theory of Interest. New York: Macmillan.

Ghazali, N. A. (2003). A Long Memory Test of the Long-Run Fisher Effect in the G7 Countries. $\begin{array}{llll}\text { Applied Financial } & \text { Economics, } & \text { 763-769. }\end{array}$ https://doi.org/10.1080/09603100210149149

Gibson, W. E. (1972). Interest Rates and Inflationary Expectations: New Evidence. American Economic Review, 62, 854-865.

Granger, C. W. J. (1969). Investigating Causal Relations by Econometric Models and Crossspectral Methods. Econometrica, 37(3), 424-438. https://doi.org/10.2307/1912791

Granger, C. W. J., \& Newbold, P. (1974). Spurious Regressions in Econometrics. Journal of Econometrics, 2(2), 111-120. https://doi.org/10.1016/0304-4076(74)90034-7

Granville, B., \& Mallick, S. (2004). Fisher Hypothesis: UK Evidence Over a Century. Applied Economics Letters, 11(2), 87-90. https://doi.org/10.1080/1350485042000200169

Gupta, K. L. (1991). Interest Rates, Inflation Expectations and the Inverted Fisher Hypothesis. Journal of Banking \& Finance, 15(1), 109-116. https://doi.org/10.1016/03784266(91)90040-S

Gül, E., \& Açıkalın, S. (2008). An Examination of the Fisher Hypothesis: the Case of Turkey. Applied Economics, 10(1), 1-5.

Hasan, H. (1999). Fisher Effect in Pakistan. The Pakistan Development Review, 38(2), 153166. https://doi.org/10.30541/v38i2pp.153-166

Hawtrey, K. M. (1997). The Fisher Effect and Australian Interest Rates. Applied Financial Economics, 7(4), 337-346. https://doi.org/10.1080/096031097333457

Huizinga, J., \& Mishkin, F. S. (1984). Inflation and Real Interest Rates on Assets With Different Risk Characteristics. Journal of Finance, 39(3), 699-714. https://doi.org/10.1111/j.1540-6261.1984.tb03659.x

Humprey, T. M. (1983). The Early History of the Real/Nominal Interest Rate Relationship. Economic Review. May/June 1983. Retrieved from https://www.richmondfed.org/ /media/richmondfedorg/publications/research/economic_r eview/1983/pdf/er690301.pdf 
Hutchison, M. M., \& Keeley, M. C. (1989). Estimating the Fisher Effect and the Stochastic Money Growth Process. Economic Inquiry, 27(2), 219-239. https://doi.org/10.1111/j.1465-7295.1989.tb00779.x

İşcan, H., \& Kaygısız, A. D. (2019). Türkiye'de Döviz Kuru, Enflasyon ve Faiz Oranı İlişkisi: 2009-2017 Uygulaması. Iğdır Üniversitesi Sosyal Bilimler Dergisi, 17, 581-604.

Jareno, F., \& Tolentino, M. (2013). The Fisher Effect: A Comparative Analysis in Europe. Jokull Journal, 63(12), 201-212.

Kesriyeli, M. (1994). Policy Regime Changes and Testing for the Fisher and UIP Hypotheses: the Turkish Evidence. Discussion Papers 9411, Research and Monetary Policy Department, Central Bank of the Republic of Turkey. https://ideas.repec.org/p/tcb/dpaper/9411.html

Kiran, B. (2013). A Fractional Cointegration Analysis of Fisher Hypothesis: Evidence from Turkey. Quality and Quantity, 47, 1077-1084. https://doi.org/10.1007/s11135-011-9584-0

Koustas, Z., \& Lamarche, J. F. (2010). Evidence of Non-Linear Mean Reversion in the Real Interest Rate. Applied Economics, 42, 237-248. https://doi.org/10.1080/00036840701579242

Koustas, Z., \& Serletis, A. (1999). On the Fisher Effect. Journal of Monetary Economics, 44, 105-130. https://doi.org/10.1016/S0304-3932(99)00017-3

Lanne, M. (2001). Near Unit Root and the Relationship Between Inflation and Interest Rates: A Reexamination of the Fisher Effect. Empirical Economics, 26, 357-366. https://doi.org/10.1007/s001810000044

Lardic, S., \& Mignon V. (2003). Fractional Co-integration Between Nominal Interest Rate and Inflation: An Examination of the Fisher Relationship in G7 Countries. Economic Bulletin, $3(14), 1-10$.

Loizides, J., \& Vamvoukas, G. (2005). Government Expenditure and Economic Growth: Evidence From Trivariate Causality Testing. Journal of Applied Economics, VIII(1), 125152. https://doi.org/10.1080/15140326.2005.12040621

Malliaropulos, D. (2000). A Note on Nonstationarity, Structural Breaks and the Fisher Effect. Journal of Banking and Finance, 24, 695-707. https://doi.org/10.1016/S03784266(99)00064-3

Marshall, A. (1890). Principles of Economics. London: Macmillan.

Mcdonald, R., \& Murphy, P. D. (1989). Testing for the Long Run Relationship Between Nominal Interest Rates and Inflation Using Cointegration Techniques. Applied Economics, 21(4), 439-447. https://doi.org/10.1080/758519711

Mill, J. S. (1865). Principles of Political Economy (6th ed.). London: Longmans, Green and Co.

Million, N. (2004). Central Bank's Interventions and the Fisher Hypothesis: A Threshold 
Cointegration Investigation. Economic Modelling, 21, 1051-1064. https://doi.org/10.1016/j.econmod.2004.03.002

Mishkin, F. S. (1981). Monetary Policy and Long-Term Interest Rates. Journal of Monetary Economics, 7, 29-55. https://doi.org/10.1016/0304-3932(81)90050-7

Mishkin, F. S. (1988). Understanding Real Interest Rates. American Journal of Agricultural Economics, 70, 1064-1072. https://doi.org/10.2307/1241737

Mishkin, F. S. (1992). Is the Fisher Effect for Real? Journal of Monetary Economics, 30, 195215. https://doi.org/10.1016/0304-3932(92)90060-F

Mundel, R. (1963). Inflation and Real Interest. Journal of Political Economy, 71, 280-283. https://doi.org/10.1086/258771

Nelson, C. R., \& Schwert, G. W. (1977). Short-Term Interest Rates as Predictors of Inflation on Testing the Hypothesis that the Real Rate of Interest is Constant. American Economic Review, 67(3), 478-486.

Olekalns, N. (1996). Further Evidence of the Fisher Effect. Applied Economics, 28(7), 851856. https://doi.org/10.1080/000368496328290

Pelaez, R. F. (1995). The Fisher Effect: Reprise. Journal of Macroeconomics, 17(2), 333-346. https://doi.org/10.1016/0164-0704(95)80105-7

Peng, W. (1995). The Fisher Hypothesis and Inflation Persistence: Evidence from Five Major Industrial Countries. IMF Working Paper No: 95/118. https://doi.org/10.5089/9781451940824.001

Phillips, P. C., \& Perron, P. (1988). Testing For A Unit Root in Time Series Regression. Biometrika, 75(2), 335-346. https://doi.org/10.1093/biomet/75.2.335

Phylaktis, K., \& Blake, D. (1993). The Fisher Hypothesis: Evidence From Three High Inflation Economies. Review of World Economics, 129(3), 591-599. https://doi.org/10.1007/BF02708004

Şimşek, M., \& Kadılar, C. (2006). Fisher Etkisinin Türkiye Verileri ile Testi. Doğuş Üniversitesi Dergisi, 7(1), 99-111. https://doi.org/10.31671/dogus.2019.265

Thornton, H. (1802). Two Speeches of Henry Thornton on the Bullion Report, May 1811. Reprinted as Appendix III to his an enquiry into the nature and effects of the paper credit of Great Britain (1802). Edited with an Introduction by FA von Hayek. New York: Rinehart and Company, Inc., 1939.

Tobin, J. (1965). Money and Economic Growth. Econometrics, 33, 671-684. https://doi.org/10.2307/1910352

Toyoshima, Y., \& Hamori, S. (2011). Panel Cointegration of the Fisher Effect: Evidence From the US, the UK and Japan. Economics Bulletin, 31(3), 2674-2682.

Tsong, C. C., \& Lee, C. F. (2013). Quantile Cointegration Analysis of the Fisher Effect. 
Journal of Macroeconomics, 35, 186-198. https://doi.org/10.1016/j.jmacro.2012.11.001

Turgutlu, E. (2004). Fisher Hipotezinin Tutarlılığının Testi: Parçalı Durağanlık ve Parçalı Koentegrasyon Analizi. Dokuz Eylül Üniversitesi İ̈BF Dergisi, 19(2), 55-74.

Westerlund, J. (2006). Panel Cointegration Tests of the Fisher Hypothesis. Lund University Department of Economics Working Papers, 10, 1-34.

Westerlund, J. (2008). Panel Cointegration Tests of the Fisher Effect. Journal of Applied Econometrics, 23, 193-233. https://doi.org/10.1002/jae.967

Wiener, N. (1956). The Theory of Prediction. In E. F. Beckenbach (Eds.), Modern Mathematics for Engineers (pp 165-190). New-York: McGraw-Hill.

Woodward, G. T. (1992). Evidence of the Fisher Effect from U.K. Indexed Bonds. The Review of Economics and Statistics, 74(2), 315-320. https://doi.org/10.2307/2109663

Xiao, Z. (2009). Quantile Cointegration Regression. Journal of Econometrics, 150, 248-260. https://doi.org/10.1016/j.jeconom.2008.12.005

Yamak, N., \& Küçükkale, Y. (1997). Türkiye'de Kamu Harcamaları Ekonomik Büyüme İlişkisi. İktisat İşletme Finans, 12(131), 5-14.

Yamak, N., \& Tanrı̈ver, B. (2007). Türkiye'de Nominal Faiz Oran1-Genel Fiyat Düzeyi İlişkisi: Gibson Paradoksu. 8. Türkiye Ekonometri ve İstatistik Kongresi İnönü Üniversitesi. Malatya. https://doi.org/10.3848/iif.1997.131.1596

Y1lanc1, V. (2009). Fisher Hipotezi’nin Türkiye için Sınanması: Doğrusal Olmayan Eşbütünleşme Analizi. Atatürk Üniversitesi İktisadi ve İdari Bilimler Dergisi, 23(4), 205213.

\section{Copyright Disclaimer}

Copyright for this article is retained by the author(s), with first publication rights granted to the journal.

This is an open-access article distributed under the terms and conditions of the Creative Commons Attribution license (http://creativecommons.org/licenses/by/3.0/). 